\title{
Effects of deuterium oxide on cell growth and vesicle speed in RBL-2H3 cells
}

For the first time we show the effects of deuterium oxide on the cell growth and vesicle transport in rat basophilic leukemia (RBL-2H3) cells. RBL-2H3 cells cultured with 15 moles/L deuterium showed decreased cell growth which was attributed to cells not doubling their DNA content. Experimental observations also showed an increase in vesicle speed for cells cultured in deuterium oxide. This increase in vesicle speed was not observed in deuterium oxide cultures treated with a microtubule-destabilizing drug suggesting that deuterium oxide affects microtubule-dependent vesicle transport. 


\section{Roshni S. Kalkur ${ }^{1, *}$, Andrew C. Ballast ${ }^{1,2, *}$, Ashley R. Triplett ${ }^{1}$, and Kathrin Spendier ${ }^{1,2}$}

${ }^{1}$ BioFrontiers Center, University of Colorado at Colorado Springs, Colorado Springs, Colorado 80918

${ }^{2}$ Department of Physics and Energy Science, University of Colorado at Colorado Springs, Colorado Springs, Colorado 80918

${ }^{*}$ These authors contributed equally to this work. 


\section{INTRODUCTION}

Roughly $70 \%$ of Earth's surface and animal bodies are made out of water $\left(\mathrm{H}_{2} \mathrm{O}\right)$. Very few, if any, biological systems or reactions will function without water and one may conclude that the properties of $\mathrm{H}_{2} \mathrm{O}$ are essential for life on Earth. In recent years research has indicated that water plays an active role in how biomolecules recognize and bind to each other (Ball, 2011). For example, in a biological system when a protein binds its ligand, associates with another protein, or folds into its functional form, the surrounding solvent must get out of the way. How water may act as a versatile intermediary and facilitator during these processes is still under investigation (Ball, 2011).

To study the effect of water $\left(\mathrm{H}_{2} \mathrm{O}\right)$, one must find ways to change the properties of $\mathrm{H}_{2} \mathrm{O}$. This can be accomplished by substituting hydrogen $(\mathrm{H})$ by its heavier deuterium (D) isotope resulting in deuterium oxide $\left(\mathrm{D}_{2} \mathrm{O}\right)$, also known as heavy water or heavy-hydrogen water. All naturally-occurring water contains approximately 150 parts per million D and therefore, $\mathrm{D}_{2} \mathrm{O}$ may be essential for some life forms (Lewis, 1934). Deuterium contains one proton and one neutron and bonds to oxygen (O) much stronger than $\mathrm{H}$ (one proton and no neutron) in $\mathrm{H}_{2} \mathrm{O}$. This results in small differences in the length of the covalent $\mathrm{H}-\mathrm{O}-$-bonds and the angles between them, thus making $\mathrm{D}_{2} \mathrm{O}$ roughly $11 \%$ denser and $25 \%$ more viscous than $\mathrm{H}_{2} \mathrm{O}$ at $20^{\circ} \mathrm{C}$ (Hardy and Cottington, 1949). Due to the natural occurrence of $\mathrm{D}_{2} \mathrm{O}$ and differences in chemical structure and physical properties compared to $\mathrm{H}_{2} \mathrm{O}$, researchers have used $\mathrm{D}_{2} \mathrm{O}$ to study the effects of water on biomolecules and cells. Studies include effects of $\mathrm{D}_{2} \mathrm{O}$ on tobacco seed growth (Lewis, 1934), IgE-Mediated histamine release from human leukocytes (Gillespie and Lichtenstein, 1972), actin filament velocities (Chaen et al., 2001), protein flexibility (Cioni and Strambini, 2002), human pancreatic tumor cells (Hartmann et al., 2005), phospholipid membranes (Beranova et al., 2012), kinesin-1 gliding assay (Maloney et al., 2014), and stabilization of tubulin as observed previously in microtubule gliding assays (Panda et al., 2000) and in biochemical experiments on isolated tubulin proteins from beef brain (Houston et al., 1974) and goat brain (Das et al., 2008). Microtubules are polarized poly-

mers of $\alpha / \beta$ tubulin heterodimers and undergo alternating phases of growth and shrinkage with sudden transitions between the two (Bartolini et al., 2005). Microtubules are responsible for a wide variety of vital 
cellular functions such as the formation of a bipolar spindle at mitosis. (Mitosis is the process, in the cell cycle, by which a cell duplicates into two genetically identical daughter cells.) However, it is still unknown how stabilization of tubulin, i.e. the stability of microtubules, due to $\mathrm{D}_{2} \mathrm{O}$ affects microtubule-dependent vesicle transport in cell cultures.

In this paper we use the RBL-2H3 cell line, a typical mast cell model system (Thomas et al., 1992; Posner et al., 1995; Carroll-Portillo et al., 2010; Spendier et al., 2010), to start investigating this question. Mast cells are immune cells that originate from the bone marrow and circulate in an immature form in the body until they settle in tissue and mucosal surfaces, where they mature. When mast cells are activated by allergens, they cause allergic responses and protect the body from parasitic infection. A key player in this activation process is the IgE-receptor complex (IgE-FceRI). Allergens or multivalent ligands, crosslink IgE-receptor complexes on the cell surface, leading to receptor phosphorylation (Metzger, 1992; Galli et al., 2008). A subsequent signaling cascade results in degranulation, i.e., fusion of secretory granules with the plasma membrane (exocytosis) to release a number of inflammatory mediators including histamine and serotonin (Galli et al., 2008). One of the paper's focus is to investigate the effect of $\mathrm{D}_{2} \mathrm{O}$ on the transport speed of these secretory granules (secretory vesicles) that are known to be transported in a direct and microtubuledependent manner towards the cell plasma membrane for exocytosis (Smith et al., 2003).

To our knowledge, the presented investigations have not been performed previously on RBL-2H3 cells. In this paper, we study the effects of $\mathrm{D}_{2} \mathrm{O}$ on RBL-2H3 cell growth and vesicle transport. For this first investigation, one specific concentration of 15 moles/ $\mathrm{L} \mathrm{D}_{2} \mathrm{O}$ was chosen. This concentration was previously reported to significantly increase histamine release in human leukocytes (Gillespie and Lichtenstein, 1972). Experiments outlined below indicate that this concentration of $\mathrm{D}_{2} \mathrm{O}$ slows RBL-2H3 cell growth and causes an increase in vesicle speed. Specifically, the data suggests an increase in vesicle speed for microtubule-dependent transport. 


\section{METHODS}

\section{Cells}

The RBL-2H3 cell line was purchased from ATCC. RBL-2H3 cells were maintained in minimal essential medium (MEM) supplemented with $10 \%$ fetal bovine serum (FBS), 1\% Penicillin Streptomycin (Pen-Strep), and $1 \%$ L-glutamine (L-glut). For the experiment cells were grown under 5\% $\mathrm{CO}_{2}$ atmosphere in 6-well dishes for up to five days with media made from MEM powder containing 0 moles/L or 15 moles/L $\mathrm{D}_{2} \mathrm{O}$. Anti-DNP IgE was purchased from Sigma-Aldrich. Before microscopy, cells were IgE primed by incubation with $0.5 \mathrm{mg} / \mathrm{mL}$ of $\operatorname{IgE}$ overnight. After the addition of cells to the microscope imaging chamber, cells were stimulated with DNP-conjugated BSA (DNP $25-\mathrm{BSA}$ ) at $2 \mu \mathrm{g} / \mathrm{mL}$ for up to 30 minutes. For colchicine drug treatment cells were treated with $100 \mu \mathrm{M}$ colchicine for 45 min (Smith et al., 2003). Trypan blue stained cells were used to count viable (alive) and dead cells on a hemacytometer. The presented studies on this cell line have been approved by the University of Colorado at Colorado Springs Institutional Review Board, approval number IBC 13-001.

\section{Supported lipid bilayers}

Prior to use, microscope glass cover slips were cleaned of organic residues with a mixture of sulfuric acid and hydrogen peroxide (piranha solution). Supported lipid bilayers (Carroll-Portillo et al., 2010; Spendier et al., 2010) were made by spontaneous liposome fusion (Werner et al., 2009). Lipids, obtained from Avanti, were dissolved in chloroform, dried under air flow, and then placed under a vacuum for $1 \mathrm{~h}$ to remove traces of oxygen. The lipid film was then suspended in PBS to $1.3 \mathrm{mM}$ and sonicated for 5 min using a probe sonicator in an ice bath. Laterally mobile bilayers were formed from 1-palmitoyl-2-oleoyl-sn-glycero-3phosphocholine (POPC) and $5 \mathrm{~mol} \% \mathrm{~N}$-dinitrophenyl-aminocaproyl phosphatidylethanolamine (DNP-Cap PE) on piranha-cleaned cover glass for 15 min on a slide warmer at $37^{\circ} \mathrm{C}$. Each bilayer coated coverslip was kept water immersed during transfer to the imaging chamber. Prior to adding cells to the bilayer, the chamber was flushed with Hanks's buffered saline solution. 


\section{Dil labeling}

For fluorescent imaging of lipid membrane vesicles, approximately $3 \times$ $10^{5}$ cells were suspended in $1 \mathrm{~mL}$ of Hanks's buffered saline solution and incubated with $2 \mu \mathrm{L}$ Vibrant DiI (Life Technologies, Grans Islan, NY) at $2 \mathrm{mM}$ concentration for 2 minutes. After incubation, the cells were washed at least three times in Hanks's buffered saline solution.

\section{Flow Cytometry measurements}

RBL-2H3 cell cycle was analyzed by quantification of DNA content with a Beckman Coulter Cytomics FC 500 MPL Flow Cytometer using forward scatter (FS), side scatter (SS), and fluorescence 3 (FL3, 620nm Band Pass Filter) channels. The brightness of the propidium iodide (PI) fluorescent dye was used to evaluate DNA content. A $488 \mathrm{~nm}$ laser beam was focused onto the flowing stream at a fixed point illuminating the cells as they pass through. To prepare cell samples, cells were first trypsinated and then washed with MEM of the appropriate $\mathrm{D}_{2} \mathrm{O}$ concentration. Cells were fixed and PI-stained by re-suspending cell pellets in $250 \mu \mathrm{L}$ of MEM, $250 \mu \mathrm{L}$ of ethanol and $100 \mu \mathrm{L}$ of PI at $0.1 \mathrm{~g} / \mathrm{L}$. PI-stained cell samples were refrigeratored overnight and analyzed the following day. Samples were run $100 \mathrm{~s}$ or until the count exceeded 10,000 cells. For analysis, the single cell population was first gated using FS vs. SS to remove obvious cell debris and non-cellular elements. This gate was then applied to FS vs. FL3 to reduce doublets, i.e. two cells stuck together that may register as a single cell. These two gates were then combined and applied to give the final PI histogram plots.

\section{Fluorescent imaging}

DiI stained RBL-2H3 cells were imaged using a total internal reflection fluorescence (TIRF) microscope. Cell samples were maintained at $37^{\circ} \mathrm{C}$ using an objective heater. In TIRF microscopy, cells were allowed to settle onto a fluid lipid POPC bilayer with 5 mol\% DNP lipid or on piranha-cleaned glass under gravity. Objective-based TIRF microscopy was performed with a S-TIRF module (Spectral Applied Research, Canada) attached to a Leica DMI3000 B inverted microscope with a $100 \times$ and 1.47 N.A. oil immersion objective using a $561 \mathrm{~nm}$ laser (Coherent Inc.) excitation. A $1.5 \times$ lens was also added to the excitation beam path resulting in a final magnification of $150 \times$. The penetration 
depth of the evanescent wave for $561 \mathrm{~nm}$ excitation was calculated to be $200 \mathrm{~nm}$. A 600/50 nm single-band bandpass filter (Chroma) was used to collect fluorescence. TIRF images were collected with an EMCCD camera (Evolve Delta; Photometrics) operated by Micro-Manager (Stuurman et al., 2007).

\section{Single-vesicle tracking}

Image processing was conducted in MATLAB (MathWorks, Inc., Natick, MA), in conjunction with the DIPImage image processing toolbox (Delft University of Technology). Image backgrounds were averaged and subtracted to reduce noise. Fluorescent particles of size within the microscope resolution limit (Gaussian variance of $200 \mathrm{~nm}$ ) were identified as vesicles. Vesicle coordinates were identified in each frame by a direct Gaussian fit algorithm and a cost function was employed to link coordinates together into trajectories (Andrews et al., 2008). Trajectories were histogrammed by average hop speed for each vesicle trajectory. Hop speed was calculated as a function of distance/frame, where each frame represents a $20 \mathrm{~ms}$ time interval. Any distinct fluorescent clusters of low speed defined as less than $10^{-2} \mu \mathrm{m} / \mathrm{s}$ were removed to separate vesicles from stationary cellular structures. The localization uncertainty for individual trajectory positions was within $100 \mathrm{~nm}$.

\section{RESULTS AND DISCUSSION}

\section{The effect of deuterium oxide on RBL-2H3 cell growth and viability}

It is known that $\mathrm{D}_{2} \mathrm{O}$ can reduce cell growth in human pancreatic tumor cells (Hartmann et al., 2005). To confirm that a similar trend is observed in RBL-2H3 cells, cell growth and cell viability was monitored over a period of 5 days. RBL-2H3 cells were cultured in 6 well plates in cell media containing 0 moles/ $/ \mathrm{D}_{2} \mathrm{O}$ or 15 moles $/ \mathrm{L}_{2} \mathrm{O}$. The plates were seeded at the same time to ensure similar initial cell seeding concentration for each well. Cells were allowed to divide for 24 hours before the first measurement. Figure 1 shows that when cells were cultured in 15 moles/L $\mathrm{D}_{2} \mathrm{O}$ (open circles) a 7-fold decrease in RBL-2H3 cell growth was observed after five days compared to cells cultured in 0 moles $/ \mathrm{L} \mathrm{D}_{2} \mathrm{O}$ (closed circles). Cell viability also dropped by $20 \%$ for cells cultured in $\mathrm{D}_{2} \mathrm{O}$ (open circles) as shown in Fig.1B. These results are qualitatively 
consistent with studies on human pancreatic tumor cells (Hartmann et al., 2005).

The observed reduction in cell growth and viability may be caused by differences in $\mathrm{pH}$ between the two growing conditions (Lardner, 2001). For cell media containing 0 moles $/ \mathrm{L} \mathrm{D}_{2} \mathrm{O}$ and 15 moles $/ \mathrm{L} \mathrm{D}_{2} \mathrm{O}$, the average $\mathrm{pH}$ was $7.58 \pm 0.29$ and $7.48 \pm 0.12$, respectively during a 5 day period. The error is represented by the standard deviation. No statistical significant difference was observed and therefore we conclude that changes in $\mathrm{pH}$ did not cause the observed decrease in cell growth.

Finally, to start investigating the effect of $\mathrm{D}_{2} \mathrm{O}$ on RBL-2H3 cell cycle, Flow Cytometry measurements were performed to monitor RBL-2H3 cell cycle by measuring DNA content (Darzynkiewicz et al., 1994). The cell cycle has four distinct phases that can be recognized in a proliferating cell population: the G1- (growth phase), S- (DNA synthesis phase), G2(growth phase and preparation for mitosis) and M-phase (mitosis). Here, PI was used as a DNA probe to investigate the cell cycle, in particular the G0-G1-, S- and G2-M-phases. Each of these phases can be identified by DNA content. G0-G1 is diploid and has a normal complement of DNA. In S-phase, DNA synthesis occurs and in the G2-M-phase, twice the amount of DNA is found in the cells than in the G0-G1 phase. Therefore, a typical DNA content frequency histogram of proliferating (multiplying) cells shows two clearly separated peaks, a G0-G1-peak and a lower G2-M-peak separated by the cell subpopulation in the S-phase.

Figure 2 depicts DNA content frequency histograms for RBL-2H3 cells in untreated cultures (Fig.2A) and in cultures treated with $\mathrm{D}_{2} \mathrm{O}$ (Fig.2B). The presented data was smoothed using a moving average and the area underneath the curve was normalized to unity. For 0 moles/L $\mathrm{D}_{2} \mathrm{O}$ treated cells, the G2-M-phase (black arrow) is recognizable in oneday (black line in Fig.2A) and four-day (red line in Fig.2A) old cultures. In other 0 moles/ $/ \mathrm{D}_{2} \mathrm{O}$ cell cultures (data not shown) the $\mathrm{G} 2-\mathrm{M}$ peak was more pronounced. In one-day old $\mathrm{D}_{2} \mathrm{O}$ treated cultures, the $\mathrm{G} 2-\mathrm{M}$-phase can also be identified (black line in Fig.2B). The number of cells entering the G2-M-phase in four-day old $\mathrm{D}_{2} \mathrm{O}$ cultures decreases, as shown by a weakened G2-M-phase and an increased height of the G0-G1 peak (red line in Fig.2B). The loss of the G2-M peak reflects that RBL-2H3 cells have not doubled their DNA content. This loss of DNA content may be caused by cells failing to enter mitosis and/or is a sign that cells are in 
the early stages of apoptosis. Both mechanisms were reported previously in human pancreatic tumor cells in which $\mathrm{D}_{2} \mathrm{O}$ induced apoptosis in PANC- 1 and AsPC- 1 cells and arrested PANC- 1 and BxPC- 3 cells in the G2-M-phase of the cell cycle (Hartmann et al., 2005). We also note that the $\mathrm{G} 0-\mathrm{G} 1$ peaks for both $\mathrm{D}_{2} \mathrm{O}$ treated and untreated cultures experience a shift of approximately the same magnitude to the left within four days. Such shifts can be attributed to daily fluctuations in the flow cytometry excitation and detection system.

\section{Dil-stained RBL-2H3 cells for vesicle tracking}

As pointed out above, one possible mechanism for failure to double DNA is cell arrest near the G2-M-phase of the cell cycle. G2-M-cell cycle arrest can be associated with problems in the mitotic spindle structure (Holy, 2002). The mitotic spindle is a structure composed of microtubules which segregates chromosomes into the daughter cells during mitosis. Besides structural support of microtubules, they also act as highways within a cell for trafficking a wide variety of cargo by molecular motors. Here we focus on secretory granules as cargo that are transported by molecular motors (kinesins) towards the cell plasma membrane for exocytosis during mast cell activation via IgE-FceRI crosslinking (Smith et al., 2003). It has been reported previously that stable microtubules result in increased Kinesin-1 motor speeds, since motors that move along dynamic microtubules could rapidly run off the end of the microtubule (Cai et al., 2009). Experiments also showed that $\mathrm{D}_{2} \mathrm{O}$ has a microtubule stabilization effect in microtubule gliding assays (Panda et al., 2000) and on isolated tubulin proteins (Houston et al., 1974; Das et al., 2008). Therefore vesicles that are transported by molecular motors in a microtubule-dependent manner should experience different transport speeds in untreated and $\mathrm{D}_{2} \mathrm{O}$ treated cultures. Specifically, the mean vesicle hop speed of tracked secretory vesicles in $\mathrm{D}_{2} \mathrm{O}$ treated cultures is expected to increase. To mark these secretory vesicles for studies presented here, diI was used as fluorescent lipophilic membrane stain (Anantharam et al., 2010). DiI is weakly fluorescent until incorporated into lipid membranes. It labels all cell membrane barriers, including the cell plasma membrane and membrane-bound organelles such as the nucleus, endoplasmic reticulum, golgi apparatus, lysosomes, endosomes, and mitochondria (see supplemental Fig.S1).

TIRF microscopy was employed to reduce background fluorescence 
from the cell plasma membrane and fluorescence from membrane-bound organelles. In TIRF microscopy, the excitation laser beam is totally internally reflected at the glass-water interface and only an evanescent wave traveling parallel to the interface penetrates into the sample. The evanescent wave decays rapidly with a perpendicular distance from the interface, and selectively excites the sample within a distance of about 200 $\mathrm{nm}$ from the surface. Besides reduction of background fluorescence, the advantage of using TIRF microscopy is selective excitation of vesicles that are within the evanescent field. In mast cells, membrane-bound granules are approximately 300-400 $\mathrm{nm}$ in diameter (Martynova et al., 2005). Therefore in the experiments outlined below, vesicles were identified as fluorescent particles of size within the microscope resolution limit. Since secretory granules are transported in a direct manner towards the cell plasma membrane for exocytosis, TIRF microscopy makes it possible to track these vesicles.

To test the ability of diI to label secretory vesicles, diI-stained, IgEloaded RBL-2H3 cells cultured in 0 moles/ $\mathrm{L} \mathrm{D}_{2} \mathrm{O}$ were allowed to settle onto glass over a $5 \mathrm{~min}$ period, and then stimulated with multivalent $\mathrm{DNP}_{25}$-BSA for $30 \mathrm{~min}$. Cells were imaged before the addition of $\mathrm{DNP}_{25}-$ BSA and during the incubation period using TIRF microscopy at 20 frames/s. Supplemental movie S1 clearly shows sustained vesicle motion 26 min after $\mathrm{DNP}_{25}$-BSA stimulation (right panel in top row of supplemental movie S1). Some vesicle motion, albeit slower, was also observed in unstimulated RBL-2H3 cells which is consistent with previous work by Smith et al. (2003). To shorten cell-settling time to less than 1 min and achieve good cell-substrate contact required for TIRF imaging, cells were allowed to settle onto a supported lipid bilayer with $5 \mathrm{~mol} \%$ DNP-Cap PE for single-vesicle tracking experiments outlined below. One of the authors showed previously that RBL-2H3 cells in contact with liganded-bilayers composed of $5 \mathrm{~mol} \%$ DNP-Cap PE exhibit degranulation levels similar to un-stimulated cells (Carroll-Portillo et al., 2010).

\section{Effect of $\mathrm{D}_{2} \mathrm{O}$ on vesicle motion in RBL-2H3 cells}

As pointed out above, diI labels all membrane barriers including vesicles that are not transported on microtubules. However, if a large number of vesicles in $\mathrm{DNP}_{25}$-BSA activated cells are tracked within the cell-substrate contact area, a significant population of these vesicles is expected to be 
secretory, i.e. vesicles that are transported on microtubules for exocytosis. Therefore, over 1500 individual vesicle were tracked using TIRF microscopy. For each vesicle-trajectory, the mean hop speed was calculated. The average of these mean vesicle hop speeds for cells cultured in 0 moles $/ \mathrm{L} \mathrm{D}_{2} \mathrm{O}$ was $3.6 \pm 0.1 \mu \mathrm{m} / \mathrm{s}$. This average speed was significantly slower than the average of $8.5 \pm 0.4 \mu \mathrm{m} / \mathrm{s}$ computed from the mean vesicle hop speeds for cells cultured in 15 moles/ $/ \mathrm{D}_{2} \mathrm{O}$. This difference was statistically significant as determined by the Student's t-test with a p-value of less than 0.05 .

To test whether some of the diI-labeled vesicles tracked with TIRF microscopy are secretory, a known microtubule destabilizing drug called colchicine was used which is expected to slow down secretory vesicle transport (Smith et al., 2003). For cells cultured in 15 moles/ $\mathrm{L} \mathrm{D}_{2} \mathrm{O}$ the average of mean vesicle hop speeds for colchicine treated cells decreased significantly to $2.4 \pm 0.3 \mu \mathrm{m} / \mathrm{s}$ as expected for microtubule-dependent vesicle transport. However, for cells cultured in 0 moles $/ \mathrm{L}_{2} \mathrm{O}$ the average of all mean hop speeds for colchicine treated cells did not significantly change and was measured to be $4.2 \pm 0.3 \mu \mathrm{m} / \mathrm{s}$. Possible reasons for not measuring a decrease in vesicle hop speed for colchicine treated cells cultured in 0 moles/ $\mathrm{L} \mathrm{D}_{2} \mathrm{O}$ are as follows. Firstly, the camera projects a three-dimensional path of a moving object onto a two-dimensional plane. Therefore, the component of vesicle velocity parallel to the substrate is not the full vesicle velocity vector. If only a small parallel component of an outward (from cell center towards cell-substrate contact zone) directed vesicle velocity vector is seen, there is no reason to insist that the parallel component by itself be large enough to generate a statistically detectable difference. 15 moles/ $\mathrm{L}_{2} \mathrm{O}$ treated cells appear to have larger vesicle velocities than 0 moles/L $\mathrm{D}_{2} \mathrm{O}$ treated cultures. Cells with larger overall vesicle velocities also have larger parallel components, and those larger parallel components show a statistically significant change with the application of colchicine. Secondly, the reported average hop speed includes both microtubule-dependent and microtubule-independent vesicle transport. Therefore, the colchicine treatment may have a different effect on these two subpopulations. Microtubules extend from the nucleus to cell surface. The disruption of microtubules results in a loss of this structures that may alter the transport of non-secretory vesicles. Once this structure is disrupted, non-secretory vesicles may be able to 
move more freely (diffuse faster), which results in an increase of the average hop speed for this specific population. This change in vesicle speed for non-secretory vesicles can counteract or dominate the expected decrease in microtubule-dependent vesicle speeds. By culturing cells in $\mathrm{D}_{2} \mathrm{O}$, it appears that microtubule-stabilization is the dominant factor that increases the overall speed of vesicle transport. Finally, vesicles with low hop speed of less than $10^{-2} \mu \mathrm{m} / \mathrm{s}$ were classified as stationary structures and therefore were not used to calculate the average of mean vesicle hop speeds. This proportion of stationary vesicles is expected to increase after treating cells with colchicine. Indeed a ten-fold increase from 0.043 to 0.418 and from 0.065 to 0.580 in 0 moles $/ \mathrm{L} \mathrm{D}_{2} \mathrm{O}$ and 15 moles $/ \mathrm{L}_{2} \mathrm{O}$ cultures was observed, respectively. This analysis shows a clear effect of colchicine on vesicle traffic in both $\mathrm{D}_{2} \mathrm{O}$ and non- $\mathrm{D}_{2} \mathrm{O}$ treated RBL-2H3 cultures.

Figure 3 shows four box plots of mean hop speeds obtained from analyzing over 1500 individual vesicle trajectories. Going from left to right, the first and second plot represent mean vesicle hop speeds in cells cultured in 0 moles/ $/ \mathrm{L}_{2} \mathrm{O}$ without colchicine $\left(\right.$ Fig. $\left.3 \mathrm{H}_{2} \mathrm{O}\right)$ and with colchicine (Fig. $3 \mathrm{H}_{2} \mathrm{O}$ with Colchicine) treatment, respectively. The third and fourth plot represent mean vesicle hop speeds in cells cultured in 15 moles/L $\mathrm{D}_{2} \mathrm{O}$ without colchicine (Fig. $3 \mathrm{D}_{2} \mathrm{O}$ ) and with colchicine (Fig.3 $\mathrm{D}_{2} \mathrm{O}$ with Colchicine) treatment, respectively. The median for mean vesicle hop speeds for cells cultured in 0 moles $/ \mathrm{L} \mathrm{D}_{2} \mathrm{O}$ was $2.3 \mu \mathrm{m} / \mathrm{s}$. This median speed was lower than the median of $5.3 \mu \mathrm{m} / \mathrm{s}$ computed from the mean vesicle hop speeds for cells cultured in 15 moles $/ \mathrm{L} \mathrm{D}_{2} \mathrm{O}$. For cells cultured in 15 moles/ $\mathrm{L} \mathrm{D}_{2} \mathrm{O}$ the median for colchicine treated cells decreased to $1.4 \mu \mathrm{m} / \mathrm{s}$ as expected. However, for cells cultured in 0 moles/ $/ \mathrm{D}_{2} \mathrm{O}$ the median of mean vesicle hop speeds for colchicine treated cells increased to $3.6 \mu \mathrm{m} / \mathrm{s}$. This comparison also indicates that colchicine treatment may have different effects on microtubule-dependent and microtubule-independent vesicle transport. It is likely that the outliers of the distributions (red crosses in Fig.3) for colchicine untreated cultures represent mean vesicle hop speeds for microtubule-dependent transport. This claim is supported by the following. Firstly, cargo transport by kinesin motors along microtubules can be faster than microtubuleindependent (diffusive) protein transport (Koon et al., 2014). Secondly, these outliers decrease significantly for colchicine treated cells cultured 
in both 0 moles/L and 15 moles/L $\mathrm{D}_{2} \mathrm{O}$. However to fully investigate deuterium oxide's microtubule stabilization effect on secretory vesicle transport, future experiments that clearly identify secretory vesicles are warranted. For example, one can follow Smith et al. (2003) and transfect RBL-2H3 cells with a green fluorescent protein-Fas ligand fusion protein (GFP-FasL) to study the transport of GFP-labeled secretory vesicles in more detail. Such investigations were out of the scope in the presented study. Nevertheless, the reported results can be used as a spring board for future investigations.

\section{CONCLUSIONS}

The primary goal of our investigations above was to study the unknown effects of $\mathrm{D}_{2} \mathrm{O}$ on RBL-2H3 cell growth and vesicle transport. A sevenfold decrease in cell growth was observed in five-day old cultures for cells grown in 15 moles/ $\mathrm{L} \mathrm{D}_{2} \mathrm{O}$ compared to untreated cells. Using Flow Cytometry, the decrease in cell proliferation was attributed to cells not sufficiently doubling their DNA content. Using TIRF microscopy in conjunction with single-vesicle tracking in antigen-stimulated and diI-labeled RBL-2H3 cells, the average vesicle hop speed increased significantly in $\mathrm{D}_{2} \mathrm{O}$ cultures and decreased after treating cells with colchicine, a microtubule-destabilizing drug. These results indicate that a subpopulation of tracked vesicles were transported along microtubules for vesicle exocytosis. This observation together with previous reports on $\mathrm{D}_{2} \mathrm{O}$ 's microtubule stabilization effect in microtubule gliding assays (Panda et al., 2000) and on isolated tubulin proteins (Houston et al., 1974; Das et al., 2008), suggest that the observed increase in vesicle hop speed for $D_{2} \mathrm{O}$ treated RBL-2H3 cultures may be due to stabilization of tubulin. Since G2-M-cell cycle arrest can be associated with problems in mitotic spindle structure (Holy, 2002), increased stability of microtubules may be the cause for the observed decrease in RBL-2H3 cell proliferation. It remains to be investigated whether $\mathrm{D}_{2} \mathrm{O}$ causes RBL-2H3 cells not to enter mitosis and/or induces apoptosis.

\section{ACKNOWLEDGMENTS}

The authors would like to thank Dr. Yuriy Garbovskiy for cell culturing, William Townend for useful discussions and help with flow cytometry 
measurements and Dr. Nathan Zameroski for useful content related discussion.

\section{REFERENCES}

Anantharam, A., Onoa, B., Edwards, R., Holz, R., and Axelrod, D. (2010). Localized topological changes of the plasma membrane upon exocytosis visualized by polarized TIRFM. J. Cell Biol., 188:415-428.

Andrews, N., Lidke, K., Pfeiffer, J., Burns, A., Wilson, B., and Oliver, J. (2008). Actin restricts FceRI diffusion and facilitates antigen-induced receptor immobilization. Nat. Cell Biol., 10:955-963.

Ball, P. (2011). More than a bystander. Nature, 478:467-468.

Bartolini, F., Tian, G., Piehl, M., Cassimeris, L., Lewis, S. A., and Cowan, N. J. (2005). Identification of a novel tubulin-destabilizing protein related to the chaperone cofactor E. J. Cell. Sci., 118:1197-1207.

Beranova, L., Humpolickova, J., Sykora, J., Benda, A., Cwiklik, L., Jurkiewicz, P., Grobnerb, G., and Hof, M. (2012). Effect of heavy water on phospholipid membranes: experimental confirmation of molecular dynamics simulations. Phys. Chem. Chem. Phys., 14:14516-14522.

Cai, D., McEwen, D., Martens, J., Meyhofer, E., and Verhey, K. (2009). Single molecule imaging reveals differences in microtubule track selection between kinesin motors. PLoS Biol., 7:e1000216.

Carroll-Portillo, A., Spendier, K., Pfeiffer, J., Griffiths, G., Li, H., Lidke, K. A., Oliver, J. M., Lidke, D. S., Thomas, J. L., Wilson, B. S., and Timlin, J. A. (2010). Formation of a mast cell synapse: FceRI membrane dynamics upon binding mobile or immobilized ligands on surfaces. J.Immunol., 184:1328-1338.

Chaen, S., Yamamoto, N., Shirakawa, I., and Sugi, H. (2001). Effect of deuterium oxide on actomyosin motility in vitro. Biochimica et Biophysica Acta, 1506:218-223.

Cioni, P. and Strambini, G. B. (2002). Effect of heavy water on protein flexibility. Biophys.J., 82:3246-3253.

Darzynkiewicz, Z., Robinson, J., and Crissman, H., editors (1994). Flow Cytometry. Methods in Cell Biology, volume 41 and 42. Academic Press, Inc., San Diego.

Das, A., Sinha, S., Acharya, B. R., Paul, P., Bhattacharyya, B., and Chakrabarti, G. (2008). Deuterium oxide stabilizes conformation of tubulin: A biophysical and biochemical study. BMB Reports, 41:62-67. 
Galli, S., Tsai, M., and Piliponsky, A. (2008). The development of allergic inflammation. Nature., 454:445-454.

Gillespie, E. and Lichtenstein, L. M. (1972). Heavy water enhances IgE-mediated histamine release from human leukocytes: evidence for microtubule involvement. Proc. Soc. Exp. Biol. Med., 140:1228-1230. Hardy, R. C. and Cottington, R. L. (1949). Viscosity of deuterium oxide and water in the range $5^{\circ} \mathrm{C}$ to $125^{\circ} \mathrm{C}$. Journal of Research of the National Bureau of Standards, Research Paper RP1994, 42:573-578.

Hartmann, J., Bader, Y., Horvath, Z., Saiko, P., Grusch, M., Illmer, C., Madlener, S., Fritzer-Szekeres, M., Heller, N., Alken, R. G., and Szekeres, T. (2005). Effects of heavy water (D2O) on human pancreatic tumor cells. Anticancer Res., 25:3407-3411.

Holy, J. M. (2002). Curcumin disrupts mitotic spindle structure and induces micronucleation in mcf-7 breast cancer cells. Mutant. Res., 518:71-84.

Houston, L. L., Odell, J., Lee, Y. C., and Himes, R. H. (1974). Solvent isotope effects on microtubule and depolymerization polymerization. J.Molec.Biol., 87:141-146.

Koon, Y., Koh, C., and Chiam, K.-H. (2014). Computational modeling reveals optimal strategy for kinase transport by microtubules to nerve terminals. PLoS ONE, 9:e92437.

Lardner, A. (2001). The effects of extracellular $\mathrm{pH}$ on immune function. J. Leukoc. Biol., 69:522-530.

Lewis, G. N. (1934). The biology of heavy water. Science, 79:151-153. Maloney, A., Herskowitz, L. J., and Koch, S. J. (2014). Effects of ${ }^{2} \mathrm{H}$ and ${ }^{18} \mathrm{O}$ water isotopes in kinesin-1 gliding assays. PeerJ, 2:e284.

Martynova, M. G., Bystrova, O. A., Moiseeva, O. M., Evdonin, A. L., Kondratov, K. A., and Medvedeva, N. D. (2005). The presence of ANP in rat peritoneal mast cells. Cell Res., 15:811-816.

Metzger, H. (1992). Transmembrane signaling: the joy of aggregation. $J$. Immunol., 149:1477-1487.

Panda, D., Chakrabarti, G., Hudson, J., Pigg, K., Miller, H. P., Wilson, L., and Himes, R. H. (2000). Suppression of microtubule dynamic instability and treadmilling by deuterium oxide. Biochemistry, 39:50755081.

Posner, R., Subramanian, K., and B., B. (1995). Simultaneous crosslinking by two nontriggering bivalent ligands causes synergistic signal- 
ing of IgE FceRI complexes. J. Immunol., 155:3601-3609.

Smith, A. J., Pfeiffer, J. R., Zhang, J., Martinez, A. M., Griffiths, G. M., and Wilson, B. S. (2003). Microtubule-dependent transport of secretory vesicles in RBL-2H3 cells. Traffic, 4:302-312.

Spendier, K., Carroll-Portillo, A., Lidke, K., Wilson, B., Timlin, J., and Thomas, J. (2010). Distribution and dynamics of rat basophilic leukemia immunoglobulin E receptors (FcERI) on planar ligand-presenting surfaces. Biophys. J., 99:388-397.

Stuurman, N., Amodaj, N., and Vale, R. D. (2007). Micro-manager: Open source software for light microscope imaging. Microscopy Today, 15:42-43.

Thomas, J., Feder, T., and Webb, W. (1992). Effects of protein concentration on $\mathrm{IgE}$ receptor mobility in rat basophilic leukemia cell plasma membranes. Biophys. J., 61:1402-1412.

Werner, J. H., Montano, G. A., Garcia, A. L., Zurek, N. A.and Akhadov, E. A., Lopez, G. P., and Shreve, A. P. (2009). Formation and dynamics of supported phospholipid membranes on a periodic nanotextured substrate. Langmuir, 25:2986-2993. 


\section{Figure 1}

Figure 1

The effect of deuterium oxide on RBL-2H3 cell (A) growth and (B) viability. Closed circles represent cells cultured with 0 moles $/ L D_{2} O$ and open circles cells cultured with 15 moles $/ L$ $\mathrm{D}_{2} \mathrm{O}$. Each data point is computed from the mean of three individual experiments and the error bar represents the standard deviation. Cells were seeded on day zero.
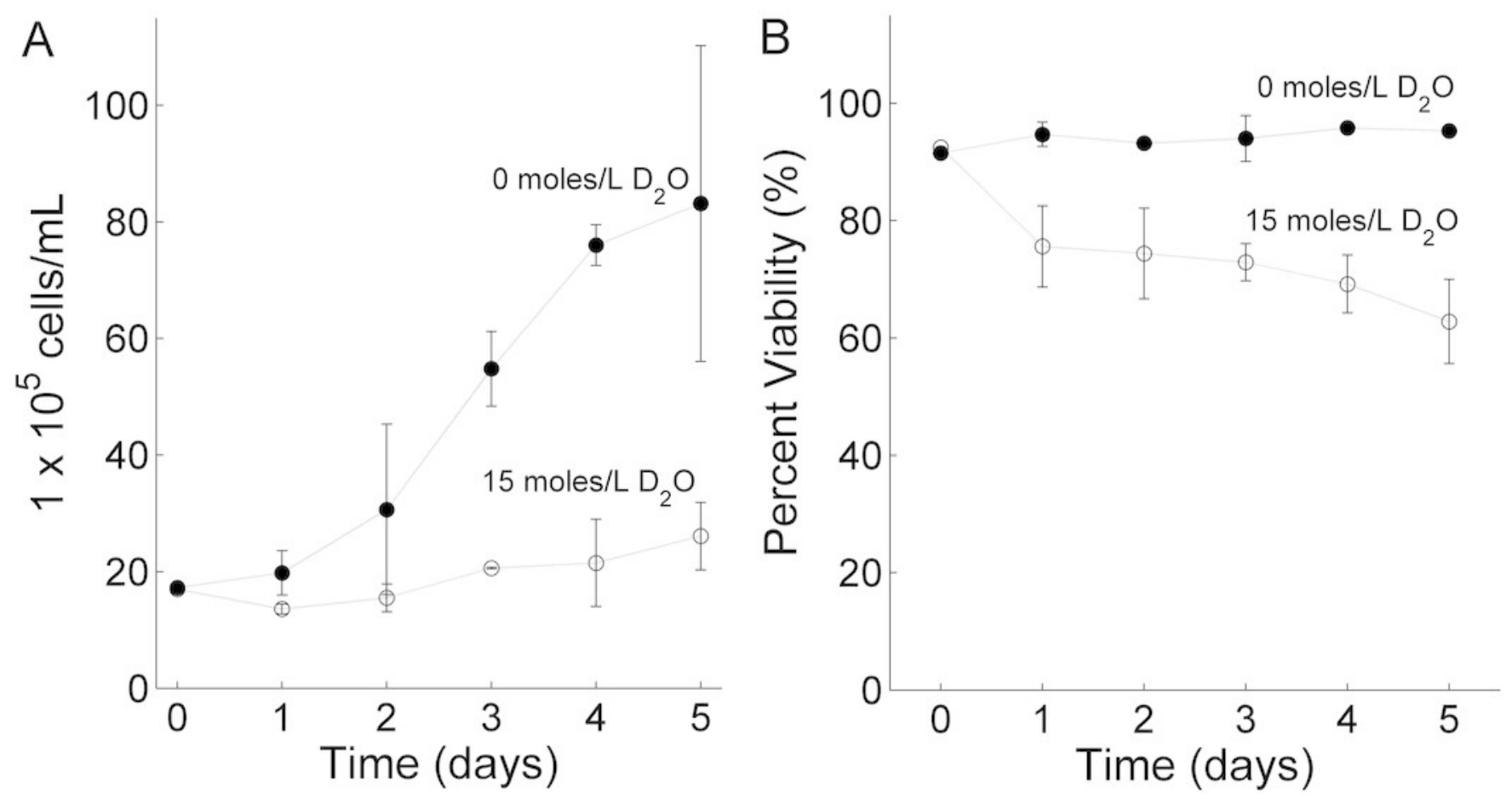


\section{Figure 2}

Figure 2

The effect of deuterium oxide on RBL-2H3 cell cycle as shown by propidium iodide intensity (FL3) histogram plots. Cell counts were normalized to unit area. Cells grown (A) in media containing 0 moles $/ L D_{2} O$ and $(B)$ in media containing 15 moles $/ L D_{2} O$. The black lines represent one-day old cultures and the red lines represent four-day old cultures. The arrows indicates position of the G2-M-cell cycle phase.
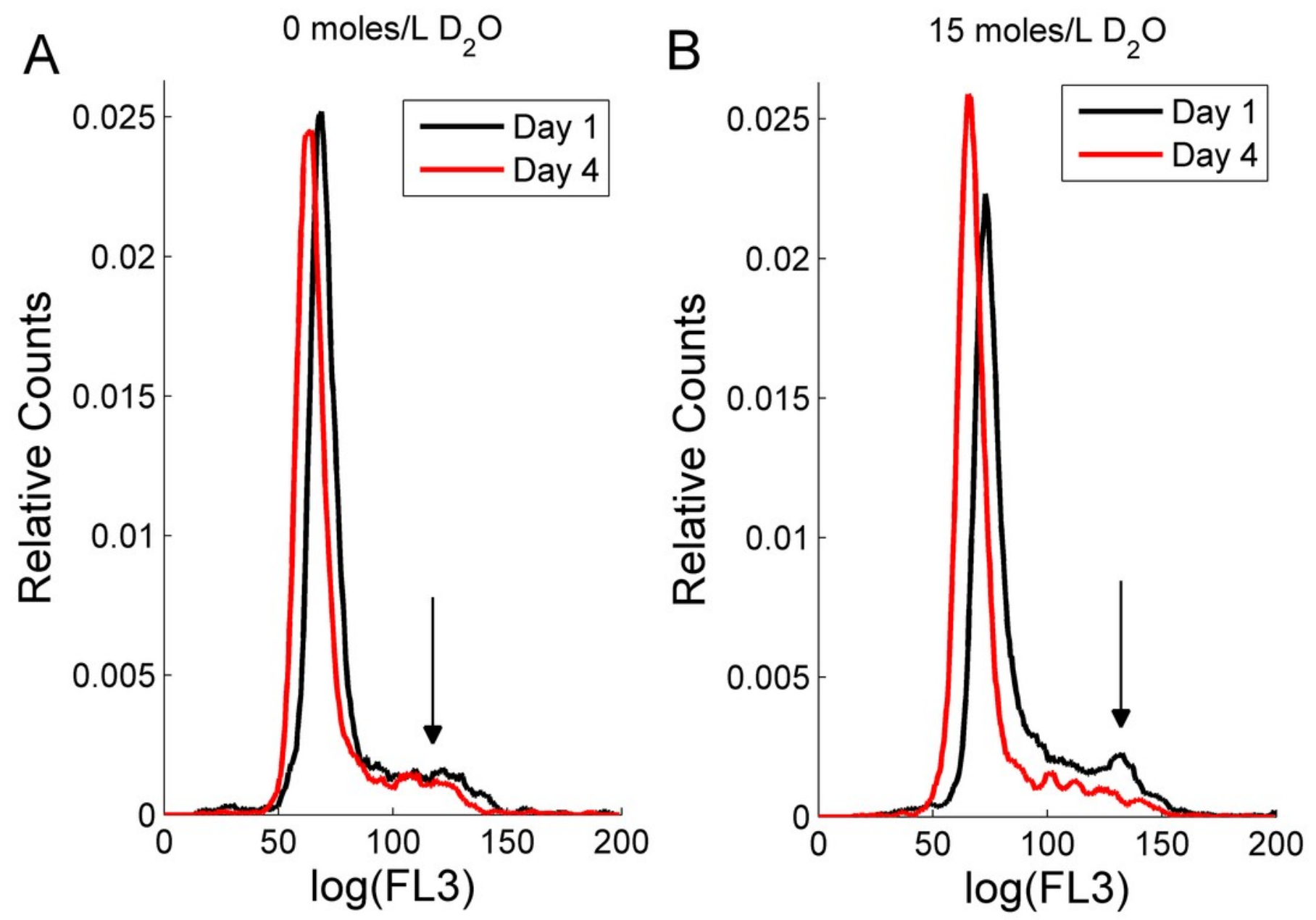


\section{Figure 3}

Figure 3

Box plots of mean vesicle hop speeds. Going from left to right plots represent mean vesicle hop speeds for cells cultured in 0 moles/ $\mathrm{L} \mathrm{D}_{2} \mathrm{O}$ without $\left(\mathrm{H}_{2} \mathrm{O}\right)$ and with $\left(\mathrm{H}_{2} \mathrm{O}\right.$ with Colchicine $)$ colchicine and cells cultured in 15 moles/L $\mathrm{D}_{2} \mathrm{O}$ without $\left(\mathrm{D}_{2} \mathrm{O}\right)$ and with $\left(\mathrm{D}_{2} \mathrm{O}\right.$ with Colchicine $)$ colchicine. The red crosses represent outliers and the red lines the median for each distribution. Going from left to right, the median for each distribution was $2.3 \mu \mathrm{m} / \mathrm{s}, 3.6 \mu \mathrm{m} / \mathrm{s}$, $5.3 \mu \mathrm{m} / \mathrm{s}$, and $1.4 \mu \mathrm{m} / \mathrm{s}$, respectively.

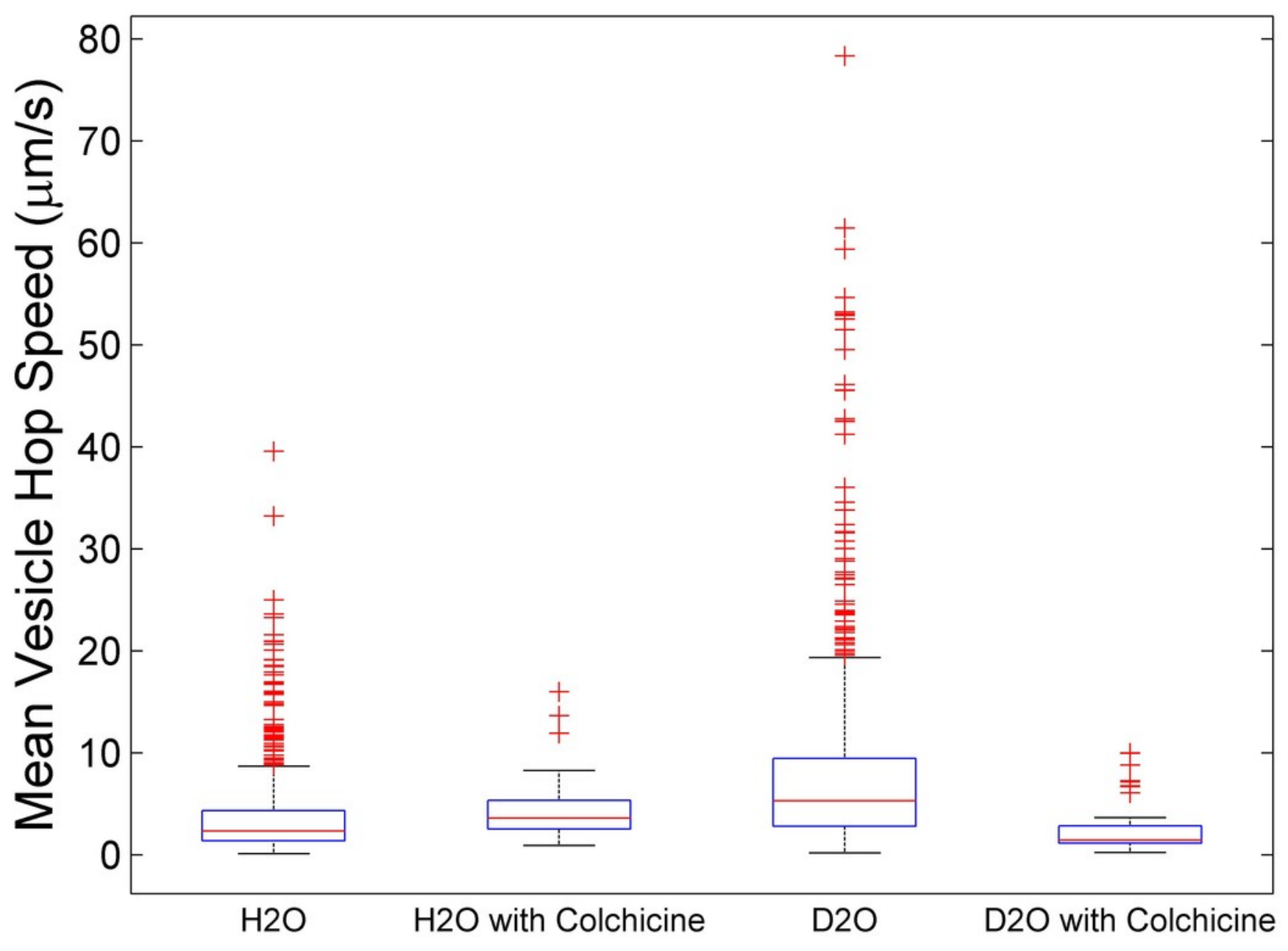

